Original Article

\title{
PESTICIDE RESIDUES IN HONEY FROM STINGLESS BEE MELIPONA SUBNITIDA (MELIPONINI, APIDAE)
}

\author{
Carolina de Gouveia M. D. E. Pinheiro ${ }^{1}$ \\ Fabiano Aurélio D. S. Oliveira² \\ Silvia Catarina S. Oloris ${ }^{3}$ \\ Jean Berg A. da Silva ${ }^{1}$ \\ Benito Soto-Blanco ${ }^{4 *}$ \\ 'Departamento de Ciências Animais, Universidade Federal Rural do Semi-Árido \\ (UFERSA), Av. Francisco Mota 572, Mossoró, RN, 59625-900, Brazil \\ 2Instituto Mineiro de Agropecuária (IMA), Av. dos Andradas 1220, Belo Horizonte, \\ MG, 30120-010, Brazil \\ ${ }^{3}$ Instituto Otávio Magalhães, Fundação Ezequiel Dias (Funed), Rua Conde Pereira \\ Carneiro 80, Belo Horizonte, MG, 30510-010, Brazil \\ 4Departamento de Clínica e Cirurgia Veterinárias, Escola de Veterinária, Universi- \\ dade Federal de Minas Gerais (UFMG), Av. Pres. Antônio Carlos 6627, Belo Horizon- \\ te, MG, 31270-901, Brazil

\section{A bstract}

The present study aimed to detect pesticide residues in the honey produced by the stingless bee Melipona subnitida. A total of thirty-five samples of honey from M. subnitida were collected from twelve municipalities of the semiarid region of Rio Grande do Norte state, northeastern Brazil. Of these thirty-five samples, fourteen were from colonies raised in an urban area, while the other twenty-one were from the countryside. The pesticides in the samples were extracted using a modified QuEChERS method. The simultaneous analysis of 116 analytes in the honey samples was performed using liquid chromatography-tandem mass spectrometry (LC-MS/MS). Twenty-five samples (71.4\% of samples) were contaminated by some amount of pesticide, and of them twenty-four had just one pesticide and one had three. The detected compounds included organophosphate pesticides (OPP) monocrotophos (24 samples), trichlorfon (6 samples) and chlorpyrifos-methyl (2 samples). In conclusion, the honey produced by the stingless bee M. subnitida may be contaminated by pesticides, which emphasizes the need for food monitoring before commercialization.

Keywords: honey, LC-MS/MS, Melipona subnitida, multiresidue analysis, pesticides residues, stingless bees

\section{INTRODUCTION}

Pesticides are widely used to protect agricultural plantations from pests, and thus improve crop production. However, inappropriate use may result in residues in human foods such as vegetables (Madureira et al., 2012), fruits (Oliveira et al., 2012), meat (Oliveira et al., 2018), fish (Oliveira et al., 2015), eggs (Hildmann et al., 2015), milk (Oliveira et al., 2014) and honey from the honeybee Apis mellifera (Pacífico da Silva et al., 2015). People consuming these contaminated foods are thus inadvertently exposed to residual pesticides, which increase the occurrence of such toxic effects as carcinogenesis, immunologic disorders and neurological disturbances (Kotsonis \& Burdock, 2013).

Beyond the risk for consumers of contaminated honey, environmental contamination by pesticides affects the health of the bees, impairing their populations. In fact, pesticides including OPP may interfere with their cognitive abilities, behavior and immune responses against pathogens, and at high concentrations, OPP may 


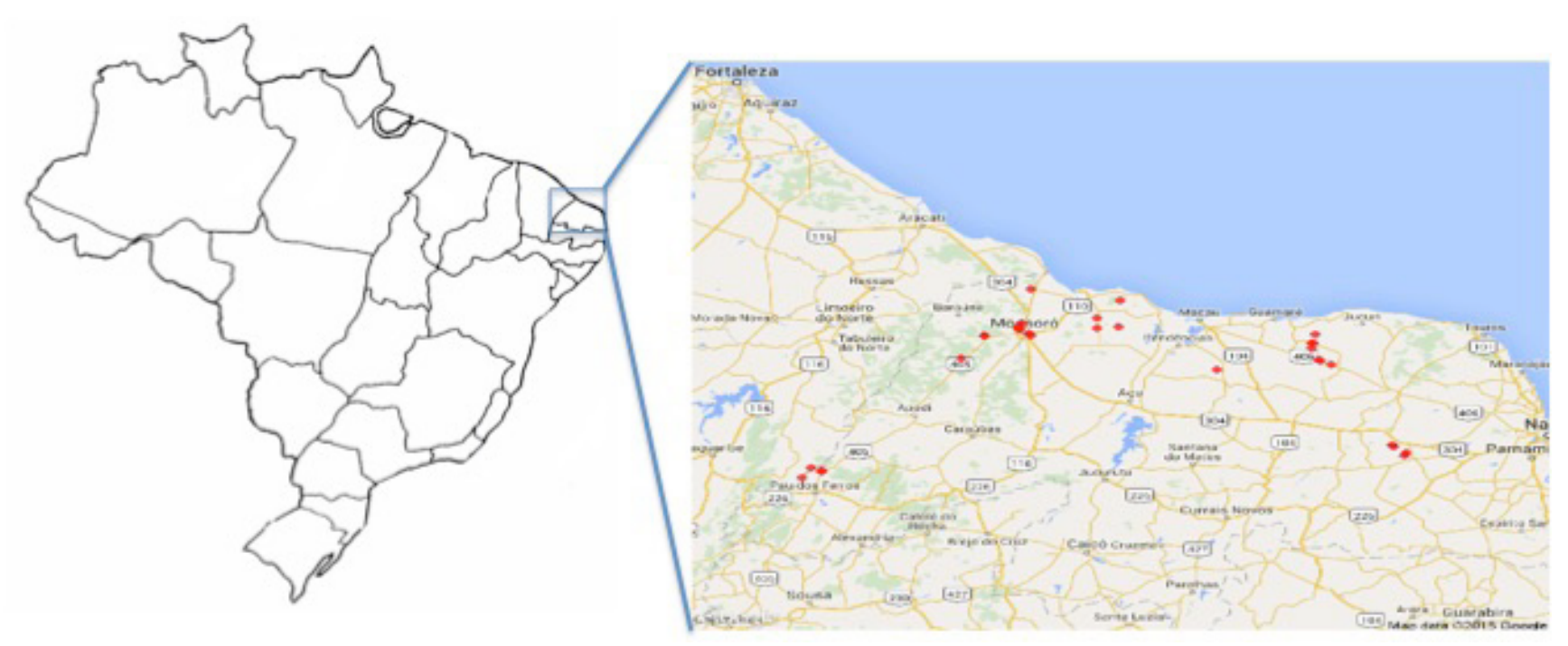

Fig. 1. Locations in Rio Grande do Norte state, northeastern Brazil, of the collection of honey samples from the stingless bee Melipona subnitida.

even prove fatal (Rortais et al., 2005; Pacífico da Silva et al., 2015; Pacífico da Silva et al., 2016). The reduction in bee population may affect agricultural production, because about $35 \%$ of crops depend on flower pollination by animals (Klein et al., 2007), and this dependence is increasing worldwide (Aizen et al., 2008; Aizen \& Harder, 2009). A number of bee species are known to act as pollinators but considerably vary in the plants they pollinate. Some pollinating bee species include the honeybee $A$. mellifera and bees from the Meliponini tribe (Maia-Silva et al., 2012).

The insects from the Meliponini tribe, Apidae family, are a large group of highly eusocial stingless bees (Camargo \& Pedro, 1992; Pedro, 2014). Several species, mostly from the Melipona genus, are used for beekeeping i.e., meliponicultur). One such species kept in Brazil is the Melipona subnitida Ducke, popularly known as "Jandaíra," with an average annual production of $2.5 \mathrm{~L}$ of honey per colony and maximum production of $5.6 \mathrm{~L}$ per colony (Cortopassi-Laurino et al., 2006). The honey from the Melipona species is commercialized as a natural medicine for children, the elderly and the sick (Jones, 2013; Carvalho, Martins, \& Mourão, 2014). Thus, this honey must be inspected for the possible presence of residual pesticides that might affect consumers.
The present study aimed to determine the occurrence of pesticide residues in the honey of $M$. subnitida. For this, the simultaneous detection of 116 analytes in the honey samples was performed using a sensitive chromatographic method by liquid chromatography-tandem mass spectrometry (LC/MS-MS) (Souza Tette et al., 2016).

\section{MATERIAL AND METHODS}

\section{Samples}

A total of thirty samples of honey produced by $M$. subnitida bees were collected from different colonies in twelve municipalities of the semiarid region of Rio Grande do Norte state, northeastern Brazil: Alto do Rodrigues (one sample), Barcelona (one sample), Galinhos (one sample), Governador Dix-Sept Rosado (one sample), Jandaíra (seven samples), Mossoró (eight samples), Pau dos Ferros (one sample), Riachuelo (two samples), São Francisco do Oeste (five samples), São Paulo do Potengi (two samples), Serra do Mel (five samples) and Tibau (one sample) (Fig. 1). From the thirty-five samples, fourteen were from colonies raised in an urban area (peripheral regions), and the other twenty-one were from the countryside. Collection was done from August to October 2013. 


\section{Sample preparation}

All analyses were performed in triplicate. The extraction procedure was adapted from the QuEChERS method (Souza Tette et al., 2016). Honey samples (5.0 g) were transferred to polypropylene tubes $(50 \mathrm{~mL})$ containing ultra-pure water $(10.0 \mathrm{~mL})$ and then the tubes were agitated at 3,000 rpm for $1 \mathrm{~min}$. A total of 10.0 $\mathrm{mL}$ acetonitrile:ethyl acetate solution (70:30) was added to each tube before being agitated again at 3,000 rpm for $1 \mathrm{~min}$. After that, $4.0 \mathrm{~g}$ magnesium sulfate and $1.0 \mathrm{~g}$ sodium acetate were added. The tubes were agitated once more at 3,000 rpm for 1 minute and then centrifuged at 4,000 rpm for $9 \mathrm{~min}$. The supernatant $(1.0 \mathrm{~mL}$ ) was transferred to a polypropylene microtube (2 $\mathrm{mL}$ ) containing $150 \mathrm{mg}$ anhydrous magnesium sulfate, $50 \mathrm{mg}$ Florisil and $50 \mathrm{mg}$ PSA (primary-secondary amine), followed by agitation at 3,000 rpm for $1 \mathrm{~min}$ and then centrifugation at $9,000 \mathrm{rpm}$ for $9 \mathrm{~min}$. The supernatant (500 $\mu \mathrm{L})$ was transferred to a vial for injection into the LC-MS/MS system.

\section{Chromatographic and mass spectrometric conditions}

The chromatographic and mass spectrometric conditions were based on an earlier study by Souza Tette et al. (2016). A UFLC system (Prominence UFLC, Shimadzu, Kyoto, Japan) composed of a Parallel-type double plunger (LC20ADXR), an auto-sampler (SIL-20AC) and a column oven (CTO-20AC), coupled to mass spectrometer with an electrospray ionization source (ESI) (5500 Triple Quad, AB SCIEX, Ontario, Canada), was used. The injection volume was $5 \mu$. The chromatographic separations were performed on a Shim-pack XR-ODSII column $(2.0 \times 100 \mathrm{~mm}, 2.2 \mu \mathrm{m})$, at a column temperature of $60^{\circ} \mathrm{C}$. The mobile phase was $10 \mathrm{mmol} / \mathrm{L}$ ammonium acetate with $0.1 \%$ formic acid (phase A) and methanol (phase B), as a gradient elution at flow rate of $0.5 \mathrm{~mL} / \mathrm{min}$. The gradient elution program was as follows: $A, 50 \%$ and $B, 50 \%$ for $7.0 \mathrm{~min} ; \mathrm{A}, 20 \%$ and $B, 80 \%$ for $4.0 \mathrm{~min} ; \mathrm{A}, 10 \%$ and $B, 90 \%$ for $0.5 \mathrm{~min} ; A, 50 \%$ and $B, 50 \%$ for $1.5 \mathrm{~min}$; total chromatographic run time, $13 \mathrm{~min}$. For the mass spectrometry analysis, an electro- spray ionization source (ESI) was used in both negative (ESI-) and positive (ESI+) modes. Source parameters were set as follows: ion spray voltage, $5.5 \mathrm{kV}$ for ESI+ and $4.5 \mathrm{kV}$ for ESI-; ion source temperature, $500^{\circ} \mathrm{C}$; curtain gas, 20 psi; nebulizer gas, 35 psi; auxiliary gas, 35 psi; collision gas, 8 psi. The tested analytes and their mass spectrometric (MS/MS) conditions, limit of detection (LOD) and limit of quantification (LOQ) are described by an earlier study (Souza Tette et al., 2016).

\section{Statistical analyses}

The statistical analyses were performed using R software version 3.1.3 (R Development Core Team, 2018). The Fisher's Exact Test from count data was used to compare the frequencies of contaminated samples from the countryside versus urban areas. The level of statistical significance was set at $P<0.05$.

\section{RESULTS}

The evaluation of the presence of pesticides in M. subnitida honey revealed that twenty-five samples $(71.4 \%)$ were contaminated by some amount of pesticide (Tab. 1). From these twentyfive positive samples, twenty-four (96.0\%) had just one pesticide detected, and just one (4.0\%) had three pesticides. The detected compounds were the organophosphate pesticides (OPP) chlorpyrifos-methyl (2 samples, $5.71 \%$ of all tested samples), monocrotophos (24 samples, $68.6 \%$ ) and trichlorfon (6 samples, 17.1\%). Residual levels exceeding the maximum residue levels (MRL; EC, 2008; EC, 2012; EC, 2018) was found for monocrotophos in $68.6 \%$ of tested samples and trichlorfon in $5.71 \%$. On the other hand, none of the tested samples showed chlorpyrifos-methyl levels over the MRL.

Of the twenty-one samples collected in the countryside, fifteen (71.4\%) were positive for some amount of pesticide, one (4.76\%) for chlorpyrifos-methyl, fourteen (66.7\%) for monocrotophos, and two (9.52\%) for trichlorfon. Within the fourteen samples from urban areas, ten (71.4\%) showed some amount of pesticide, one (7.14\%) for chlorpyrifos-methyl, ten (71.4\%) for 
Table 1.

Detected pesticide levels in 35 tested samples of honey from the stingless bee Melipona subnitida

\begin{tabular}{|c|c|c|c|c|c|}
\hline $\begin{array}{l}\text { Sample } \\
\text { number }\end{array}$ & Municipality & Collection site & $\begin{array}{c}\text { Chlorpyrifos-methyl } \\
(\mathrm{mg} / \mathrm{kg})\end{array}$ & $\begin{array}{l}\text { Monocrotophos (mg/ } \\
\mathrm{kg} \text { ) }\end{array}$ & $\begin{array}{l}\text { Trichlorfon } \\
\text { (mg/kg) }\end{array}$ \\
\hline 1 & Alto do Rodrigues & Countryside & n.d. a & 0.055 & n.d. \\
\hline 2 & Barcelona & Countryside & n.d. & n.d. & n.d. \\
\hline 3 & Galinhos & Countryside & n.d. & n.d. & n.d. \\
\hline 4 & Governador Dix-Sept Rosado & Countryside & n.d. & 0.072 & n.d. \\
\hline 5 & Jandaíra & Urban & n.d. & n.d. & n.d. \\
\hline 6 & Jandaíra & Urban & n.d. & 0.038 & n.d. \\
\hline 7 & Jandaíra & Countryside & n.d. & 0.057 & n.d. \\
\hline 8 & Jandaíra & Countryside & n.d. & n.d. & n.d. \\
\hline 9 & Jandaíra & Countryside & n.d. & 0.015 & n.d. \\
\hline 10 & Jandaíra & Countryside & n.d. & 0.021 & n.d. \\
\hline 11 & Jandaíra & Urban & $<\mathrm{LOQ}^{\mathrm{b}}$ & 0.049 & $<$ LOQ \\
\hline 12 & Mossoró & Urban & n.d. & 0.081 & n.d. \\
\hline 13 & Mossoró & Urban & n.d. & 0.018 & n.d. \\
\hline 14 & Mossoró & Urban & n.d. & 0.057 & n.d. \\
\hline 15 & Mossoró & Urban & n.d. & 0.033 & $<$ LOQ \\
\hline 16 & Mossoró & Urban & n.d. & n.d. & n.d. \\
\hline 17 & Mossoró & Urban & n.d. & n.d. & n.d. \\
\hline 18 & Mossoró & Urban & n.d. & 0.062 & $<$ LOQ \\
\hline 19 & Mossoró & Urban & n.d. & 0.050 & 0.023 \\
\hline 20 & Pau dos Ferros & Countryside & n.d. & n.d. & n.d. \\
\hline 21 & Riachuelo & Countryside & n.d. & 0.037 & n.d. \\
\hline 22 & Riachuelo & Countryside & $<L O Q$ & n.d. & n.d. \\
\hline 23 & São Francisco do Oeste & Urban & n.d. & 0.061 & n.d. \\
\hline 24 & São Francisco do Oeste & Urban & n.d. & 0.052 & n.d. \\
\hline 25 & São Francisco do Oeste & Countryside & n.d. & 0.074 & n.d. \\
\hline 26 & São Francisco do Oeste & Countryside & n.d. & 0.011 & n.d. \\
\hline 27 & São Francisco do Oeste & Countryside & n.d. & n.d. & n.d. \\
\hline 28 & São Paulo do Potengi & Countryside & n.d. & n.d. & n.d. \\
\hline 29 & São Paulo do Potengi & Countryside & n.d. & n.d. & n.d. \\
\hline 30 & Serra do Mel & Countryside & n.d. & 0.043 & 0.074 \\
\hline 31 & Serra do Mel & Urban & n.d. & 0.033 & 0.059 \\
\hline 32 & Serra do Mel & Countryside & n.d. & 0.046 & n.d. \\
\hline 33 & Serra do Mel & Countryside & n.d. & 0.056 & n.d. \\
\hline 34 & Serra do Mel & Countryside & n.d. & 0.024 & n.d. \\
\hline \multirow[t]{7}{*}{35} & Tibau & Countryside & n.d. & 0.101 & n.d. \\
\hline & \multicolumn{2}{|c|}{ Median (mg/kg) } & 0 & 0.049 & 0 \\
\hline & \multicolumn{2}{|c|}{ Minimum (mg/kg) } & 0 & 0 & 0 \\
\hline & \multicolumn{2}{|c|}{ Maximum (mg/kg) } & 0.005 & 0.101 & 0.074 \\
\hline & \multicolumn{2}{|c|}{ MRL c (mg/kg) } & 0.050 & 0.010 & 0.010 \\
\hline & \multicolumn{2}{|c|}{ Samples $>M R L$} & 0 & 24 & 2 \\
\hline & \multicolumn{2}{|c|}{$\%$ samples $>M R L$} & 0 & 68.6 & 5.71 \\
\hline
\end{tabular}

a n.d.: not detected

b < LOQ: lower than limit of quantification $(0.010 \mathrm{mg} / \mathrm{kg})$

c MRL: maximum residue levels (EC, 2008; EC, 2012; EC, 2018)

ग. 
monocrotophos and four (28.6\%) for trichlorfon. A comparison of the frequencies of pesticides between both areas showed no significant difference $(P>0.05$, Fisher's Exact Test from count data).

\section{DISCUSSION}

In the present study, M. subnitida honey showed three OPP: monocrotophos, trichlorfon, and chlorpyrifos-methyl. The residual levels exceeded the maximum residue levels (MRL; EC, 2008; EC, 2012; EC, 2018) for monocrotophos (68.6\% samples) and trichlorfon (5.71\%). This contamination of the honey might be attributed to environmental contamination, due to inappropriate agricultural utilization of pesticides. In fact, in a region near where our study was conducted, the water was found to contain residual levels of pesticides including chlorpyrifos (Gama, Oliveira, \& Cavalcante, 2013; Pinheiro et al., 2017) and monocrotophos (Pinheiro et al., 2017).

Earlier studies also aimed to search residual pesticide levels in honey in Brazil and found OPP. Pacifico da Silva et al. (2015) found nineteen different pesticides after testing fifty-three honey samples form the Rio Grande do Norte state, Northeastern Brazil. Seven of these pesticides were OPP: chlorpyrifos, ethion, paraoxon, parathion, phosalone, and sulfotep. On the other hand, Souza Tette et al. (2016) tested one hundred honey samples from five states of Brazil, but just the organophosphorus trichlorfon was found in one sample.

The frequencies of pesticides from colonies raised in an urban area and from the countryside were similar (71.4\%). This finding indicates that both colonies had similar foraging patterns, which was reinforced by a pollen analysis of all tested honey samples showing about $52 \%$ of the amount of pollen from Mimosa tenuiflora (data not shown). In fact, M. subnitida bees can fly distances of up to $4,000 \mathrm{~m}$ to forage (Silva et al., 2014).

Due to their high toxicity, monocrotophos and trichlorfon as insecticides have not been not allowed to be used in Brazil since 2006 and 2010, respectively (ANVISA, 2006; ANVISA, 2010). However, the use of such illegal compounds as pesticides is frequent in Brazil due to the high difference in market price (Lemos, Carvalho, \& Ortiz, 2018). Illegal commerce has health and environmental concerns, and in fact both monocrotophos and trichlorfon were found in honey in the present study in levels higher than MRL. Thus, this finding reinforces the risk to human health due to use of illegal compounds that might contaminate food.

OPP are a commonly used class of insecticides with hundreds of commercial compounds available worldwide. Its primary toxic mechanism is the inhibition of acetylcholinesterase (AChE), an esterase that hydrolyzes the neurotransmitter acetylcholine. Fatal acute poisoning is due to the over-stimulation of cholinergic receptors in the peripheral and central nervous systems. Some OPP may induce delayed polyneuropathy days after a single exposure (Costa, 2006). The residual levels of OPP found in honey in our study were too low to produce either of these two toxic effects, but the consumption of contaminated honey might contribute to chronic OPP exposure.

Some epidemiological studies in humans connected long-term exposure to low doses of OPP with the development of neuropsychological disturbances. Furthermore, studies using laboratory animals have shown neurobehavioral interferences by doses lower than those that induce cholinergic signs of poisoning (Ray \& Richards, 2001). One possible mechanism is the induction of neuroinflammation by OPP that potentially results in neurodegeneration and neurodegenerative disorders (Banks \& Lein, 2012; Nurulain et al., 2014). Monocrotophos was found to inhibit AChE activity and induce oxidative stress in the brain of rats exposed to doses lower than No Observed Effect Level (Karumuri et al., 2019). Thus, we hypothesize that people who continuously consume this contaminated honey might be at risk of developing these neuropsychological disturbances.

Another risk associated with chronic OPP exposure is the development of cancer (Mostafalou \& Abdollahi, 2013). Several epide- 
miological studies conducted in farmers and commercial pesticide applicators have shown an increased risk for several types of cancer due to OPP exposure. Among the OPP compounds found in the honey samples in our study, an increased risk for development of non-Hodgkin lymphoma by exposure to chlorpyrifos, and trichlorfon (Waddell et al., 2001) and lung cancer by chlorpyrifos (Lee et al., 2004) were found.

In conclusion, the honey produced by the stingless bee $M$. subnitida may be contaminated by pesticides, which emphasizes the need for food monitoring before commercialization. The high frequency of positive samples (71.4\%) found in our study is indicative of environmental contamination, probably due to the inappropriate agricultural utilization of pesticides.

\section{ACKNOWLEDGMENTS}

The authors are grateful for the financial support from the Fundação de Amparo à Pesquisa do Estado de Minas Gerais - FAPEMIG (Grants APQ02304-16 and BIP-00056-17) and Conselho Nacional de Desenvolvimento Científico e Tecnológico - CNPq (Grant 305761/2013-7).

\section{REFERENCES}

Aizen, M.A., Garibaldi, L.A., Cunningham, S.A., \& Klein, A.M. (2008). Long-term global trends in crop yield and production reveal no current pollination shortage but increasing pollinator dependency. Current Biology, 18(20), 1572-1575. DOl: 10.1016/j. cub.2008.08.066

Aizen, M.A., \& Harder, L.D. (2009). The global stock of domesticated honey bees is growing slower than agricultural demand for pollination. Current Biology(1), 19, 915-918. D0l: 10.1016/j.cub.2009.03.071

ANVISA - Agência Nacional de Vigilância Sanitária (2006). Resolução-RDC No 215, de 14 de dezembro de 2006. Diário Oficial da União - Seção 1, 240, p.127. 15/12/2006. http://pesquisa.in.gov.br/imprensa/jsp/visualiza/index.jsp?jornal=1\&pagina=127\&da ta $=15 / 12 / 2006$

ANVISA - Agência Nacional de Vigilância Sanitária
(2010). Resolução-RDC No- 37, de 16 de agosto de 2010 - Regulamento técnico para o ingrediente ativo Triclorfom em decorrência da reavaliação toxicológica. Diário Oficial da União - Seção 1, 158, p.46-47. 18/08/2010. http://pesquisa.in.gov.br/imprensa/jsp/visualiza/index.jsp?.jornal=1\&pagina=46\& data=18/08/2010

Banks, C.N., \& Lein, P.j. (2012). A review of experimental evidence linking neurotoxic organophosphorus compounds and inflammation. Neurotoxicology, 33(3), 575-584. DOl: 10.1016/j.neuro.2012.02.002

Camargo, J.M.F., \& Pedro, S.R.M. (1992). Systematics, phylogeny and biogeography of the Meliponinae (Hymenoptera, Apidae): a mini-review. Apidologie, 23(6), 509-522. DOl: 10.1051/apido:19920603

Carvalho, R.M.A., Martins, C.F., \& Mourão, J.S. (2014), Meliponiculture in Quilombola communities of Ipiranga and Gurugi, Paraíba state, Brazil: an ethnoecological approach. Journal of Ethnobiology and Ethnomedicine, 10, 3. DOI: 10.1186/1746-4269-10-3

Cortopassi-Laurino, M., Imperatriz-Fonseca, V.L., Roubik, D.W., Dollin, A., Heard, T., Aguilar, I., ... Nogueira-Neto, P. (2006). Global meliponiculture: challenges and opportunities. Apidologie, 372), 275-292. DOl: 10.1051/apido:2006027

Costa, L.G. (2006). Current issues in organophosphate toxicology. Clinica Chimica Acta, 366(1-2), 1-13. DOl: 10.1016/j.cca.2005.10.008

EC. (2008). Commission Regulation (EC) No 149/2008 of 29 January 2008 amending Regulation (EC) No 396/2005 of the European Parliament and of the Council by establishing Annexes II, III and IV setting maximum residue levels for products covered by Annex I thereto. Official Journal of the European Union, L 58, 1-398. 1.3.2008.

EC. (2012). Commission Regulation (EU) No. 899/2012 amending Annexes II and III to Regulation (EC) No. 396/2005 of the European Parliament and of the Council as regards maximum residue levels for acephate, alachlor, anilazine, azocyclotin, benfuracarb, butylate, captafol, carbaryl, carbofuran, 
carbosulfan, chlorfenapyr, chlorthal-dimethyl, chlorthiamid, cyhexatin, diazinon, dichlobenil, dicofol, dimethipin, diniconazole, disulfoton, fenitrothion, flufenzin, furathiocarb, hexaconazole, lactofen, mepronil, methamidophos, methoprene, monocrotophos, monuron, oxycarboxin, oxydemeton-methyl, parathion-methyl, phorate, phosalone, procymidone, profenofos, propachlor, quinclorac, quintozene, tolylfluanid, trichlorfon, tridemorph and trifluralin in or on certain products and amending that Regulation by establishing Annex $V$ listing default values Text with EEA relevance. Official Journal of the European Union, L 273, 1-75. 6.10.2012

EC. (2018). Commission Regulation (EC) No 2018/686 of 4 May 2018amending Annexes II and III to Regulation (EC) No 396/2005 of the European Parliament and of the Council as regards maximum residue levels for chlorpyrifos, chlorpyrifos-methyl and triclopyr in or on certain products. Official Journal of the European Union, L 137, 30-62. 16.5.2018.

Gama, A.F., Oliveira, A.H.B., \& Cavalcante, R.M. (2013). Inventário de agrotóxicos e risco de contaminação química dos recursos hídricos no semiárido cearense. Química Nova, 36(3), 462-467. DOl: 10.1590/S010040422013000300017

Hildmann, F., Gottert, C., Frenzel, T., Kempe, G., Speer, K. (2015). Pesticide residues in chicken eggs - a sample preparation methodology for analysis by gas and liquid chromatography/tandem mass spectrometry. Journal of Chromatography A, 1403, 1-20. DOl: 10.1016/j.chroma.2015.05.024

Jones, R. (2013). Stingless bees: a historical perspective. In: P. Vit, S.R.M. Pedro, \& D. Roubik (Eds.), PotHoney, a legacy of stingless bees (pp.219-227). New York: Springer.

Karumuri, S.B., Singh, H., Naqvi, S., Mishra, A., Flora, S.J.S. (2019). Impact of chronic low dose exposure of monocrotophos in rat brain: oxidative/ nitrosative stress, neuronal changes and cholinesterase activity. Toxicology Reports, 6, 1295-1303. DOl: 10.1016/j. toxrep.2019.11.005

Klein, A.-M., Vaissière, B.E., Cane, J.H., Steffan-Dewenter, I., Cunningham, S.A., Kremen, C., Tscharntke, T.
(2007). Importance of pollinators in changing landscapes for world crops. Proceedings of the Royal Society B: Biological Sciences, 274(1608), 303-313. DOl: 10.1098/rspb.2006.3721

Kotsonis, K.N., \& Burdock, G.A. (2013). Food toxicology. In: C.D. Klaassen (Ed.), Casarett \& Doull's Toxicology: The Basic Science of Poisons (8th ed., pp.13051356). New York: McGraw-Hill.

Lee, W.J., Blair, A., Hoppin, J.A., Lubin, J.H., Rusiecki, J.A., Sandler, D.P., Dosemeci, M., Alavanja, M.C. (2004). Cancer incidence among pesticide applicators exposed to chlorpyrifos in the Agricultural Health Study. Journal of the National Cancer Institute, 96(23), 17811789. DOI: 10.1093/jnci/djh324

Lemos, V.F., Carvalho, A.C.B., \& Ortiz, R.S. (2018). Perfil nacional de apreensões de agrotóxicos pela Polícia Federal. Revista Brasileira de Criminalística, 71), 21-25. DOl: 10.15260/rbc.v7i1.258

Madureira, F.D., Oliveira, F.A.S., Souza, W.R., Pontelo, A.P., Oliveira, M.L.G., Silva, G. (2012). A multi-residue method for the determination of 90 pesticides in matrices with a high water content by LC MS/ MS without clean-up. Food additives \& contaminants. Part A, Chemistry, analysis, control, exposure \& risk assessment, 2944), 665-678. DOl: 10.1080/19440049.2011.623837

Maia-Silva, C., Silva, C.I., Hrncir, M., Queiroz, R.T., Imperatriz-Fonseca, V.L. (2012). Guia de Plantas Visitadas por Abelhas na Caatinga [Guide of plants visited by bees in Caatinga]. Fortaleza: Editora Fundação Brasil Cidadão.

Mostafalou, S., \& Abdollahi, M. (2013). Pesticides and human chronic diseases: Evidences, mechanisms, and perspectives. Toxicology and Applied Pharmacology, 268(2), 157-177. DOl: 10.1016/j.taap.2013.01.025

Nurulain, S.M., Adeghate, E., Sheikh, A., Yasin, J., Kamal, M.A., Sharma, C., Adem, A., Ojha, S. (2014). Sub-chronic exposure of non-observable adverse effect dose of terbufos sulfone: neuroinflammation in diabetic and non-diabetic rats. CNS \& Neurological Disorders - Drug Targets, 13(8), 1397-1405. DOl: 10.2174/187 1527313666141023142539 
Oliveira, M.L.G., Madureira, F.D., Oliveira, F.A.S., Pontelo, A.P., Silva, G., Oliveira, R., Paes, C. (2012). A multi-residue method for the determination of pesticides in high water content matrices by gas chromatography single quadrupole mass spectrometry with electron ionisation (El-GC/MS). Food Additives \& Contaminants. Part A, Chemistry, Analysis, Control, Exposure \& Risk Assessment, 29(4), 657-664. DOl: 10.1080/19440049.2011.642102

Oliveira, F.A.S., Madureira, F.D., Lopes, R.P., Ferreira, M.G., Soto-Blanco, B., Melo, M.M. (2014). Optimization of chromatographic conditions and comparison of extraction efficiencies of four different methods for determination and quantification of pesticide content in bovine milk by UFLCMS/MS. Química Nova, 3710), 1699-1706. DOl: 10.5935/0100-4042.20140264

Oliveira, F.A.S., Reis, L.P.G., Soto-Blanco, B., \& Melo, M.M. (2015). Pesticides residues in the Prochilodus costatus (Valenciennes, 1850) fish caught in the São Francisco River, Brazil. Journal of Environmental Science and Health, Part B, 50(6), 398-405. DOl: 10.1080/03601234.2015.1011946

Oliveira, F.A.S., Pereira, E.N.C., Gobbi, J.M., Soto-Blanco, B., Melo, M.M. (2018). Multiresidue method for detection of pesticides in beef meat using liquid chromatography coupled to mass spectrometry detection (LC-MS) after QuEChERS extraction. Food Additives \& Contaminants, Part A, 35(1), 94-109. DOl: 10.1080/19440049.2017.1395519

Pacífico da Silva, I., Oliveira, F.A.S., Pedroza, H.P., Gadelha, I.C.N., Melo, M.M., Soto-Blanco, B. (2015). Pesticide exposure of honeybees (Apis mellifera) pollinating melon crops. Apidologie, 46(6), 703-715. DOl: 10.1007/s13592-015-0360-3

Pacífico da Silva, I., Melo, M.M., \& Soto-Blanco, B. (2016). Efeitos tóxicos dos praguicidas para abelhas [Toxic effects of pesticides to bees]. Revista Brasileira de Higiene e Sanidade Animal, 10(1), 142-157. DOl: 10.5935/1981-2965.20160013
Pedro, S.R.M. (2014). The stingless bee fauna in Brazil (Hymenoptera: Apidae). Sociobiology, 67(4), 348354. DOl: 10.13102/sociobiology.v61i4.348-354

Pinheiro, A.S., Milhome, M.A.L., Ferreira, F.E.D.R., Costa, R.S., Santos, J.L.G., Oliveira, L.K.B., Amorim, A.V. (2017). Potencial de contaminação em águas superficiais pelo uso de agrotóxicos em Iguatu, Ceará. Revista Craibeiras de Agroecologia, 7(1), 1-5.

R Development Core Team (2018). R: A language and environment for statistical computing. Vienna: R Foundation for Statistical Computing.

Ray, D.E., \& Richards, P.G. (2001). The potential for toxic effects of chronic, low-dose exposure to organophosphates. Toxicology Letters, 12011-2), 343351. DOl: 10.1016/S0378-4274(01)00266-1

Rortais, A., Arnold, G., Halm, M.P., \& Touffet-Briens, F. (2005). Modes of honeybees exposure to systemic insecticides: estimated amounts of contaminated pollen and nectar consumed by different categories of bees. Apidologie, 36(1), 71-83. DOl: 10.1051/ apido:2004071

Silva, A.G., Pinto, R.S., Contrera, F.A.L., Albuquerque, P.M.C., Rêgo, M.M.C. (2014). Foraging distance of Melipona subnitida Ducke (Hymenoptera: Apidae). Sociobiology, 67(4), 494-501. DOl: 10.13102/sociobiology.v61i4.494-501

Souza Tette, P.A., Oliveira, F.A.S., Pereira, E.N., Silva, G., de Abreu Glória, M.B., Fernandes, C. (2016). Multiclass method for pesticides quantification in honey by means of modified QuEChERS and UHPLC-MS/ MS. Food Chemistry, 217, 130-139. DOl: 10.1016/j. foodchem.2016.05.036

Waddell, B.L., Zahm, S.H., Baris, D., Weisenburger, D.D., Holmes, F., Burmeister, L.F., Cantor, K.P., Blair, A. (2001). Agricultural use of organophosphate pesticides and the risk of non-Hodgkin's Iymphoma among male farmers (United States). Cancer Causes \& Control, 12(6), 509-517. DOI: 10.1023/A:1011293208949 